\title{
Improving Coefficient of Thermal Performance and Electricity Saving in the Water Chiller System
}

\author{
SARA Q. HAMZA, RAFID M. HANNUN
}

MSc. Mechanical Eng. Dept., College of Eng., Thi -Qar University, Iraq sarahalsamawy@ gmail.com

Prof.Dr. Mechanical Eng., College of Eng., Thi -Qar University, Iraq rafid.alsaleh@gmail.com

\begin{abstract}
:
A water chiller air-conditioning system has been completed. Energy savings was estimated using different variables: calculation power consumption, electricity consumption, the cooling load of the testing room. The system tested during the environment of Al- Muthanna province (Al-Rummaitha city), Iraq. The measurements were taken during the summer months (May - June - July and August).

The results indicated a difference in energy saving during the daily operating hours, the highest reduction rate was obtained of cooling loads, which were based on the change in evaporator temperatures and also the highest percentage was achieved during August by $23 \%$ and the lowest percentage during May by $5 \%$. Thus, the study concluded that the percentage of electricity consumption during the months of May and August was $56 \%$ and $41 \%$, respectively.

This paper concludes the power electricity was 14.7 amperes in conventional air conditioners whereas the chiller airconditioning was up to 1.07 amperes. Also, the electricity saving was effected with lower storage tank water.
\end{abstract}

Keywords: water chiller, Energy saving, Cost saving

\section{Introduction}

The air conditioning system is responsible for a large part of the energy consumption in the building or rooms. Therefore, the capacity of the system in air conditioning design should be determine the total cooling loads required. Thus, consideration should be given at the thermal gain that generated during the cracks, external and internal surfaces which have a significant influence on the cooling process.

In present day, air conditioning is necessary in hot and humid weather to keep human comfort in internal environments. Air conditioning has become an important application, which works on dehumidification and cooling in commercial, residential and industrial areas [1].

Briefly, the present chiller air conditioning system considers as a closed system, which the chilled water flowing through the coils, chillers or other heat exchangers forms a closed recirculating loop in a closed system, the water doesn't exposed to the atmosphere pressure during its flowing process. The advantage of this device is could place it in any part of the house. The flow of water is remains constant at any cross-sectional in the system during the operating time, also the purpose of fluid recirculation is to save water and energy. [2].

Most of the previous research has focused on the energy saving methods of large chiller air conditioning as a study. Zhang, et.al (2006)[3] introduced a new idea to improve the energy efficiency of the water-chiller system and suggested that the traditional multi-chiller system be integrated into a single cooling system by connecting the compressors, evaporators and capacitors in parallel with a cooling capacity of $120 \mathrm{~kW}$. The results have showed a good reduction in performance due to a good decrease in condensation temperature and some increase in the evaporator temperature as well as the increase in COP by $16.2 \%$ in the simulation and $9.5 \%$ in the experiment.

Chowdhury, (2009)[4] studied the modeling and analysis of an air-cooled chiller system of a building in Australia. The results showed a good energy savings, where the cooling organization can provide electricity consumption of about $36 \%$ per year used for air conditioning in the building. It was found that application of the pre-cooling and economizer system could save $115 \mathrm{~kW} / \mathrm{m}^{2} /$ month and $72 \mathrm{~kW} / \mathrm{m}^{2} /$ month total cooling energy and $26 \mathrm{~kW} / \mathrm{m}^{2} /$ month and $42 \mathrm{~kW} / \mathrm{m} 2 /$ month chiller energy, respectively.

Jeon, et.al (2010)[5] studied a hybrid system combining the screw water cooler with a ground source pump (GSHP). It was measured and analyzed in different cooling loads. The results showed improvement and cooling required as cooling loads for the building were $8 \%$ and $12.4 \%$, respectively. The coefficient of thermal performance has increased by $7 \%$ of the system as compare to conventional chiller.

Hao, et.al (2013)[6] proposed a method to increase energy efficiency by associating evaporative coolant with air coolant. Evaporative air-cooled chiller (EACC) was simulated using weather data for every four cities in China. It has been found that there is a possibility to save energy when using the (pad thickness) between $2.4 \%$ and $14 \%$ as compared to the conventional air-cooled chiller.

Kabeel, et.al (2017)[7] investigated an evaporative air cooled chiller that used by cold mist water and tested experimentally. The water mist was cooled with a small amount of water through a heat exchanger chiller. It obtained a good performance coefficient COP as compared to the performance of the conventional airchiller as it reached $82 \%$. The experimental results also showed that system is an effective system and has a significant enhancing the performance of the system and thus reducing the demand on electricity consumption. The 
improvement also included air temperature and relative humidity.

In this paper we will discuss the methods of energy saving in the small chiller system to get the best energy saving.

The present study aims to investigate the chiller-air conditioning system experimentally by using R-134a and water as refrigerants which studied the effect of energy saving for cooling loads during summer months, power electricity, and percentage coefficient of performance (COP) in chiller-air conditioning.

\section{Characteristics of the water chiller-air conditioning system}

The water chiller system, as shown in Fig .1 consists of two different process fluid loops; air-conditioning loop and water chiller Loop. This system behavior as a compression refrigeration system which includes: a compressor, a storage tank, a condenser and an evaporator. A refrigerant flows during these units in a closed loop.

The compressor is used to increase the pressure of the vapor refrigerant flowing from the evaporator. The storage tank is installed after the compressor to decrease the power consumption by increasing the heat removable (i.e. lowering the storage water temperature). Thus, a reducing in the compressor power consumption is results from returning the additional amount of release refrigerant to the inlet of the compressor. The refrigerant at high temperature and pressure then converts to the condenser. The condenser is associated with the compressor to reject the heat. The pressure and the temperature of the refrigerant has been reduces by using the expansion device until converts to the evaporator, where the chiller flows in a heat exchanger, discharging heat for the water to absorb it. Then the cold water chiller is circulating by water pump and pipeline into storage tank [8].

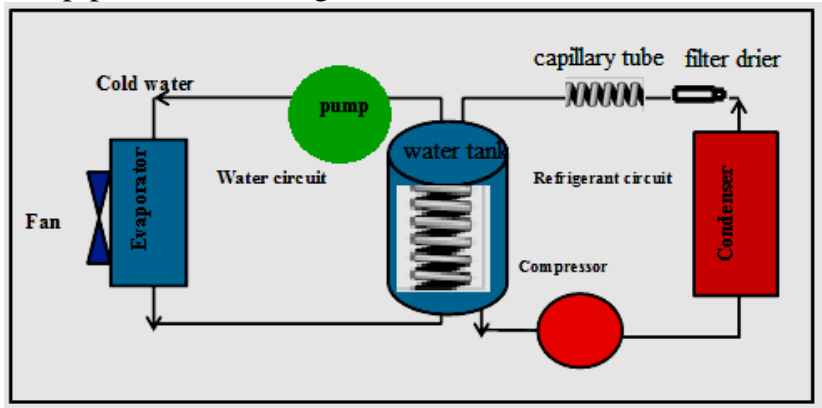

Fig .1 Schematic of the water chiller air- conditioning cycle

\section{Modelling of theoretical energy saving}

The cooling loads of selected room with using water chiller air-conditioning system is calculated by subtract the heat transfer rate between chiller and the cooling loads without chiller system [9].

$Q_{\mathrm{ii}}=Q_{\mathrm{i}}-Q$

Where:

$Q_{i}$; cooling load for selected room without chiller system (kW)
$Q_{\mathrm{ii}}$ : cooling load for selected room with chiller system ( $\mathrm{kW}$ )

The percentage of reduction in cooling loads of selected room with using chiller system is calculated by:

Load Reduction $=\frac{\mathrm{Qi}_{\mathrm{i}-\mathrm{Qii}}}{\mathrm{Qi}} * 100 \%(2)$

The total consumed electricity in $(\mathrm{kWh})$ for cooling of selected system with and without chiller for 24 hours and 30 days from each month is calculated from:

E. $C^{i}=\frac{Q^{i}(\mathrm{BTU} / \mathrm{h})}{\frac{\mathrm{BER}}{Q^{\mathrm{ii}}}} * \frac{1}{1000} * 24 * 30$
E. $C^{i i}=\left(\frac{\mathrm{BTU} / \mathrm{h})}{\mathrm{BER}}\right) * \frac{1}{1000} * 24 * 30$

Where;

E. $C^{\mathrm{i}}$ :

Total power consumption without chiller system (kW)

E. Cii :

Total power consumption with chiller system (kW)

EER: which is represents the ratio of cooling or heating capacity in (BTU/h) to the input power

The energy saving which can be obtained with using chiller system is determining by;

Energy saving $=\frac{E \cdot C^{i}-E \cdot C^{i \mathrm{ii}}}{E \cdot C^{i}} * 100 \%$

Coefficient of performance enhancement percentage, COP, due to using cooled water tank is calculated by [10]:

cop)h-cop)l

cop)h

where COP)h-COP)l refers to high and low value of coefficient of performance percentage through months of the unit at testing, as shown in Fig.8 and Table. 1 .

Table.1 value of coefficient of performance percentage

\begin{tabular}{|c|c|c|}
\hline Month & COP\% & $\begin{array}{c}\text { Return Water } \\
\text { Temperature }\end{array}$ \\
\hline May & $7 \%$ & 11.6 \\
\hline Jun & $10 \%$ & 14.4 \\
\hline July & $11 \%$ & 17.3 \\
\hline Aug & $17 \%$ & 17.5 \\
\hline
\end{tabular}

\section{Experimental model}

An experimental study as shown in the Fig.2 and Table .2 was carried out in order to evaluate the work of the air conditioning chiller at operating conditions such as rate of electricity saving, humidity rate, calculation of the amount of cooling, coefficient of performance and energy consumption. This study is done in a room with dimensions ( $4 \mathrm{~m}$ length, $4 \mathrm{~m}$ width, and $3 \mathrm{~m}$ high) 
and ambient temperature $\left(30^{\circ} \mathrm{C}\right)$ during the period from May to Aug 2018, where the weather in the southern regions of Iraq is characterized by high temperature that makes the traditional cooler work with less efficient.

Table .2 General description of the experimental system

\begin{tabular}{|c|l|}
\hline Components & \multicolumn{1}{|c|}{ Specifications } \\
\hline Compressor & $\begin{array}{l}\text { Type: hermetic } \\
\text { reciprocating } \\
\text { Capacity: } 1 / 5 \mathrm{HP}, \mathrm{LBP} \\
\text { Power consumption: 0.6Amp }\end{array}$ \\
\hline \multirow{3}{*}{ Condenser } & $\begin{array}{l}\text { Size: (5.52m) length, (5mm) } \\
\text { outer diameter } \\
\text { Fin type: wire mesh }\end{array}$ \\
\hline \multirow{2}{*}{ Evaporator } & $\begin{array}{l}\text { Size: } 40 \mathrm{~cm} \text { width, } 41.5 \mathrm{~cm} \text { height } \\
\text { and } 7 \mathrm{~cm} \text { in thickness } \\
\text { Fin type: aluminum fins }\end{array}$ \\
\hline $\begin{array}{c}\text { Heat } \\
\text { exchanger }\end{array}$ & $\begin{array}{l}\text { Inner diameter: } 2.5 \mathrm{~mm} \\
\text { Length: } 2.5 \mathrm{~m}\end{array}$ \\
\hline $\begin{array}{l}\text { Size: } 30 \mathrm{~cm} \text { diameter, and 35 cm } \\
\text { height } \\
\text { Length: } 15.24 \mathrm{~m} \text { coiled inside } \\
\text { the tank of water } \\
\text { Inner diameter: } 5 \mathrm{~mm} \text { diameter } \\
\text { coiled }\end{array}$ \\
\hline
\end{tabular}

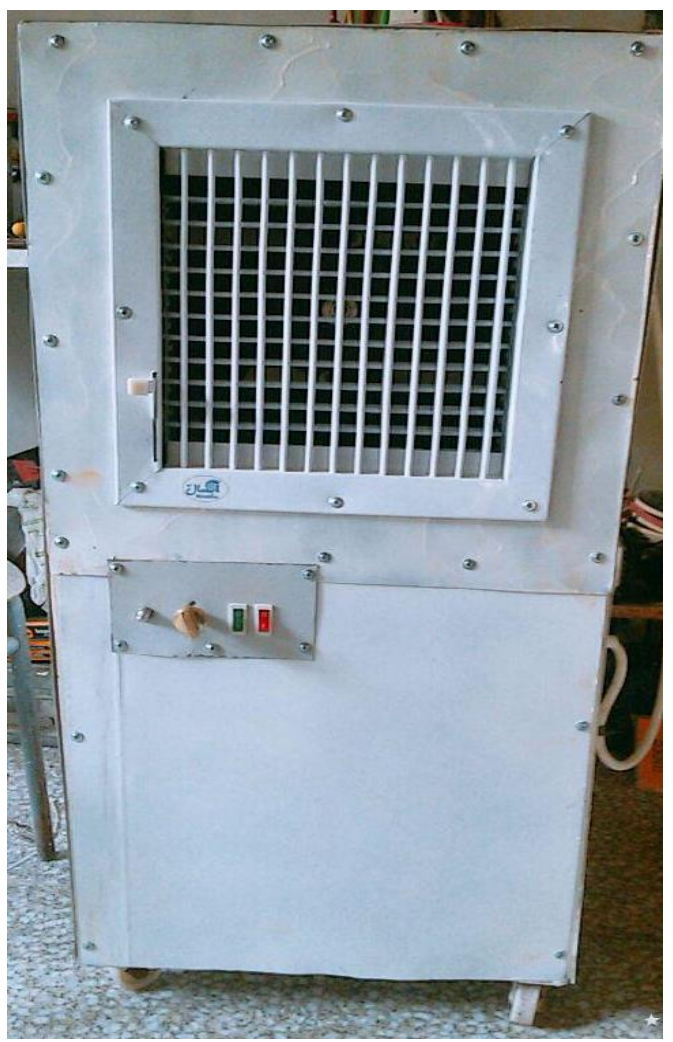

Fig.2. Photographs of experimental model

\section{Results and discussions}

\subsection{Cost saving}

To clarify the saving in capital with using water chiller air-conditioning as a contribution system for cooling of the selected room, the cost of electricity consumption that chosen for cooling selected room with and without chiller system is considered according to the prices of Iraqi Electricity Ministry [11].

The total cost of consumed electricity for cooling loads during summer months with airconditioning system is shown in Table .3. This table showed that the maximum cost for electricity consumption with chiller airconditioning system was recorded during August month. Also this table showed that there is a saving in capital with using water chiller system and this saving varies from 9,864ID (7.8\$) during May month to 11,016ID (8.8\$) during August month. Additionally this table clarified that total saving in capital from all summer months that reached to 41,832 IQD (33.2\$).

Table.3 The total cost of the consumed electricity for cooling for the selected room with and without chiller system.

\begin{tabular}{|c|c|c|c|c|}
\hline Month & $\begin{array}{c}\text { Electricity } \\
\text { cost } \\
\text { without } \\
\text { chiller } \\
\text { (IQD) }\end{array}$ & $\begin{array}{c}\text { Electricity } \\
\text { cost } \\
\text { With } \\
\text { chiller } \\
\text { (IQD) }\end{array}$ & $\begin{array}{c}\text { Saving } \\
\text { cost } \\
\text { (IQD) }\end{array}$ & $\begin{array}{c}\text { Saving } \\
\text { cost }\end{array}$ \\
\hline May & 10,656 & 792 & 9,864 & 7.8 \\
\hline June & 10,944 & 864 & 10,080 & 8 \\
\hline July & 11,808 & 936 & 10,872 & 8.6 \\
\hline August & 12,096 & 1,080 & 11,016 & 8.8 \\
\hline All & 45,504 & 3,672 & 41,832 & 33.2 \\
months & & & & \\
\hline
\end{tabular}

\subsection{Energy saving}

After specifying the suitable system, the results of energy saving can be obtained with using water chiller air-conditioning system for cooling, power consumption and electricity of the selected laboratory room during summer months (May, June, July and August) are selected.

Fig.3 and Fig.4 indicates the variation of energy saving during daily hours and compressor power consumption at four months. It can be noted from this behavior that the best reduction in power consumption of water chiller- air conditioning system was during May. Also, the highest power consumption for the water chiller and conventional air-conditioning system was in August. Due to the hours which have higher 
outside air temperature during summer season which proportional with need for cooling and energy consumption.

The amount of cooling load for selected room during summer months with and without chiller air-conditioning system is illustrated in Fig. 5. It can be seen that the amount of cooling load varies along summer months depending on the variation in evaporator temperature. The maximum amount was recorded during May and the minimum was recorded during August because these months have the lower and highest evaporator temperature respectively.

to show the part of water chiller air-conditioning system on the reduction of cooling load requirement and as a importance reduction the energy consumption, the percentage of reduction in the amount of cooling load is calculated according to Eq. (2) and illustrated in Fig. 6 It can be observed that the percentages of reduction in cooling load with using water chiller airconditioning system during summer months range from 5\% during May to 23\% through August.

The electricity consumption for cooling of selected room during summer months with and without chiller system is presented in Fig. 7. From this figure It can be found that the maximum amount of the consumed electricity was recorded during August while the minimum was in May. The electricity consumption based on the amount of cooling load where the minimum and maximum amount of cooling load was recorded at these months.

Fig. 8 shows the percentages of energy saving during summer months with using chiller airconditioning system which computed based on Eq.(5). It seems that the percentages of energy saving are relatively range between $44 \%$ and 70 $\%$. The maximum energy saving can be obtained during August whereas the minimum amount in energy saving was recorded during May because maximum and minimum reduction in cooling load recorded through August and May respectively.

Fig.9 shows the overall thermal performance of the system is influenced by the operation parameters such as the storage tank average water temperature, storage tank volume. it is clear from that a lower storage temperature used results higher energy efficiency. Thus, with a lower storage tank water temperature level, more electricity savings can be expected.

As a result the COP reduction of water chiller system is obtained by $7.4 \%$ at $11.6^{\circ} \mathrm{C}$ storage tank water temperature while it is found by $17 \%$ at $18.6^{\circ} \mathrm{C}$

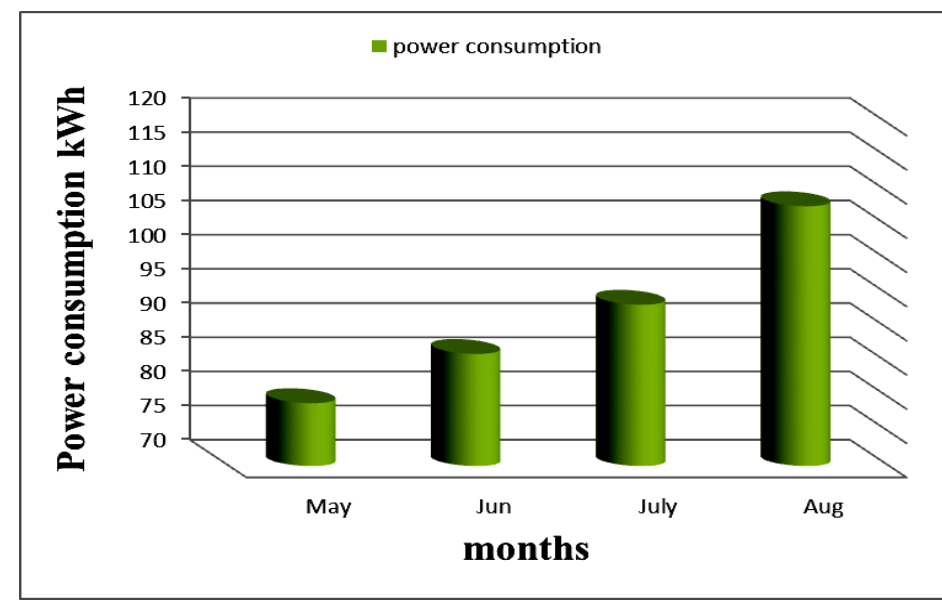

Fig. 3 The monthly power consumption for the water chiller air-conditioning system

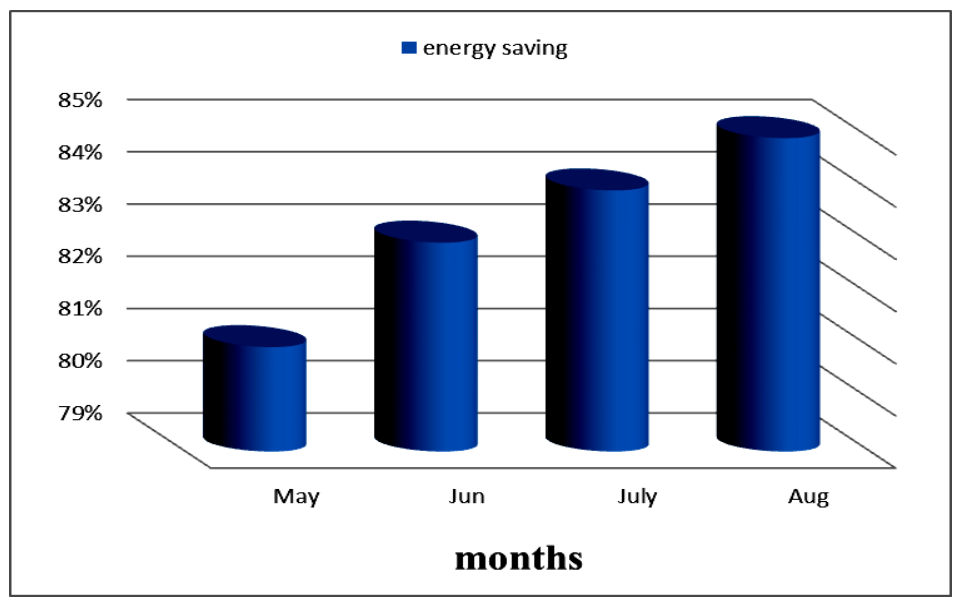

Fig. 4 The energy saving of power consumption for the water chiller and conventional air-conditioning system.

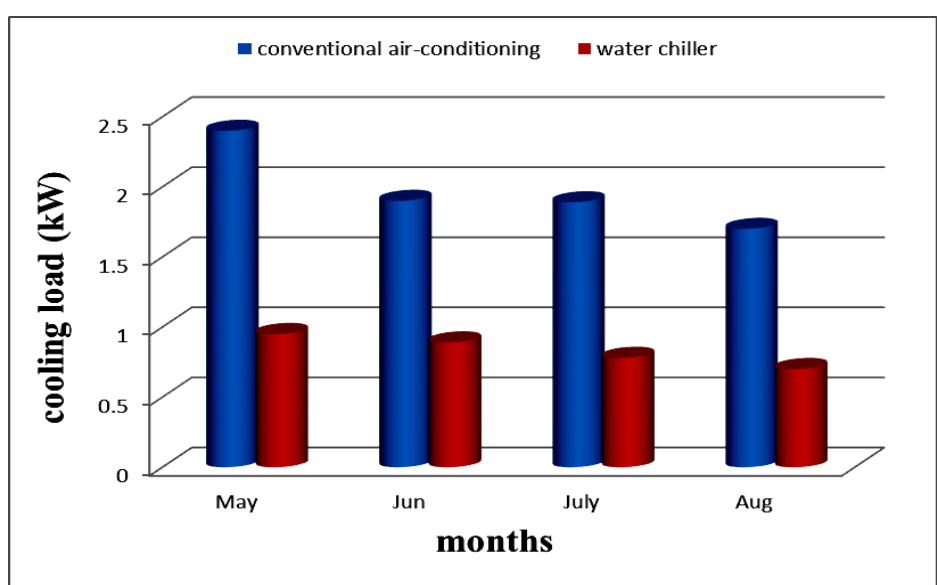

Fig. 5 The cooling load for selected room with conventional air-conditioning system during summer month 


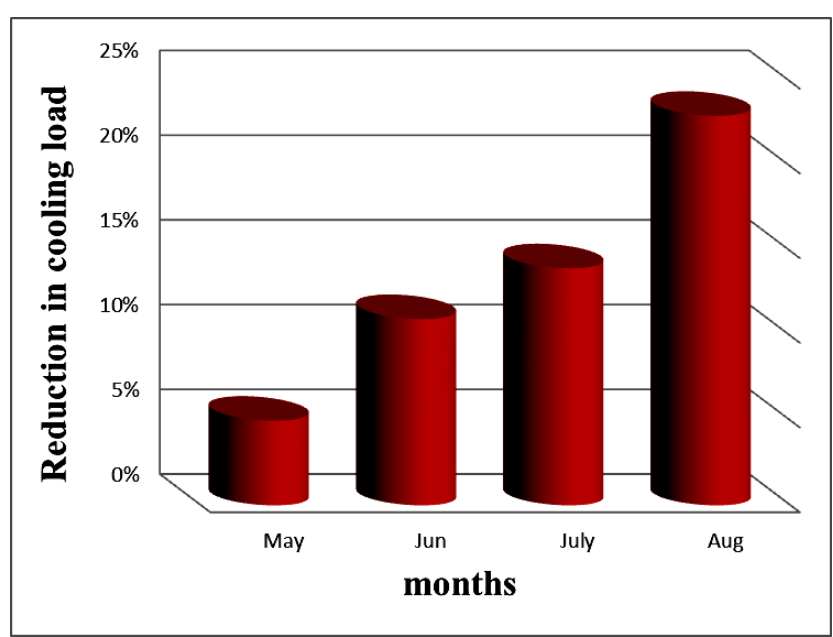

Fig. 6 The reduction in cooling load for selected room with using water chiller air-conditioning system during summer months.

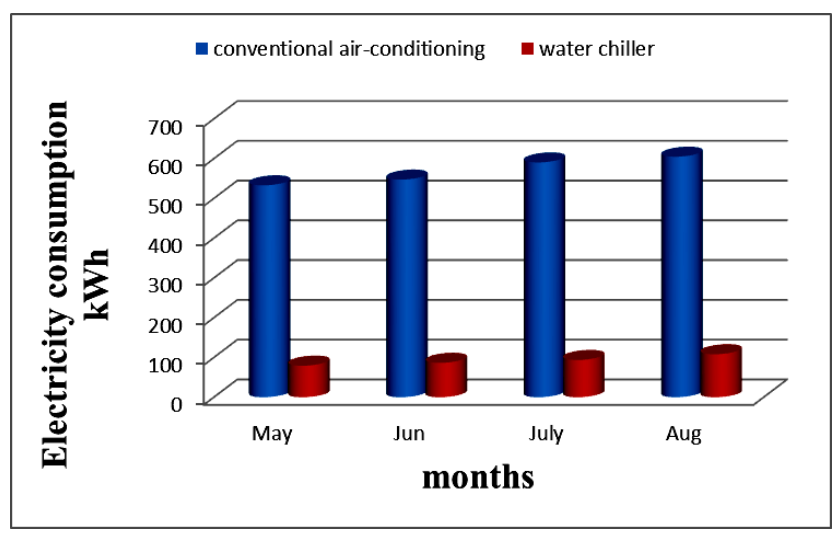

Fig. 7 Electricity consumption for cooling of selected room with and without water chiller system through summer months.

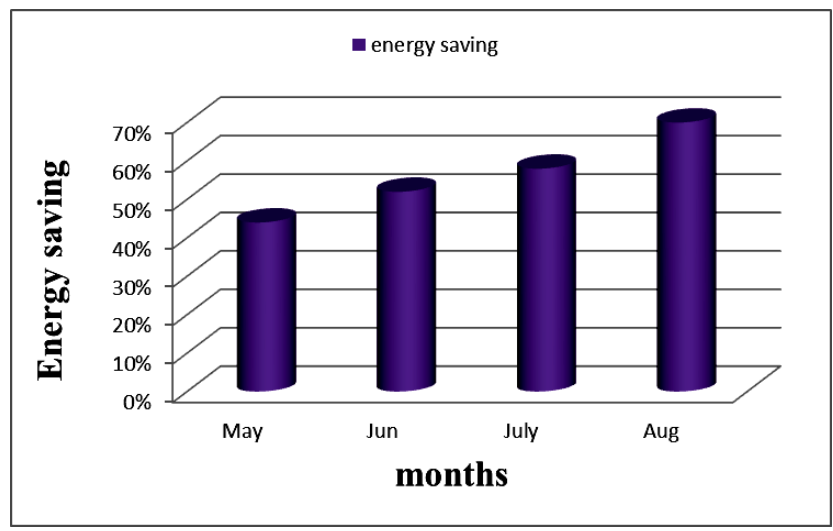

Fig. 8 Energy saving occurs with using chiller system for cooling selected room during summer months.

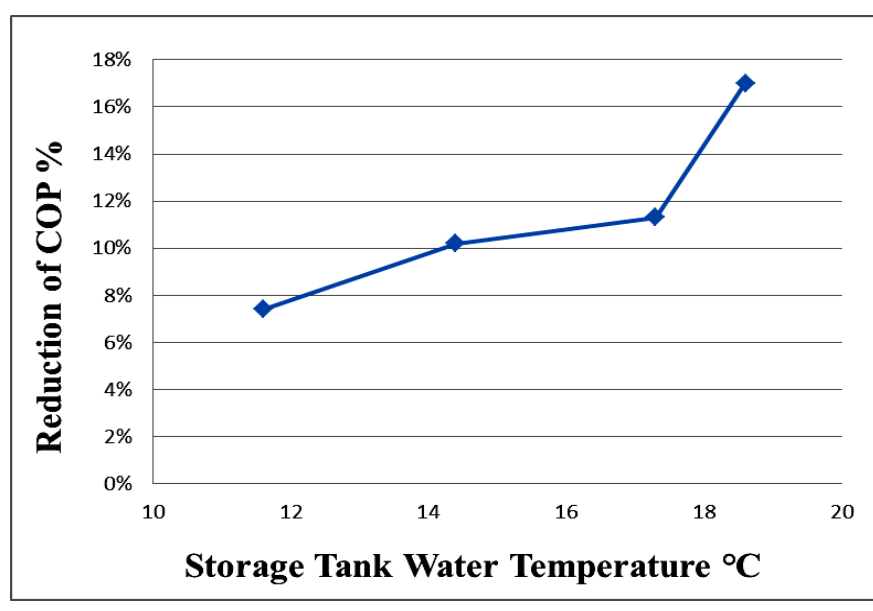

Fig.9 Variation of the storage tank water temperature effect on percentage coefficient of performance (COP).

\section{Conclusion}

The application of water chiller system was emphasized for regions of hot weather condition. A new design for employing heat exchanger cooling tank to cool the water was introduced and considered. These conclusions can be summarized as follows:

1. Water chiller system by using R-134a refrigerant is an energy efficient system. On hot days, using water tank as a heat exchanger cooling in water cooled system could increase the total system COP of the present case study by about $50 \%$ and hence reduce the electricity demand.

2. Water chiller system is very promising for hot and dry regions.

3. Evaporator water temperature decreases, system COP increases.

4. The maximum reduction in cooling load for selected room by using water chiller system reached to $23 \%$ at August.

5. With using water chiller system the total electricity consumption for cooling decreases and this leads to best energy saving was $85 \%$ at May.

6. The maximum power consumption by using water chiller system reached to 85 $\%$ at August.

7. COP for proposed system is higher than that for the conventional air conditioning about $7.4 \%$.

8. The total saving in cost of the consumed electricity for all selected months of reached to 41,832 ID (33.2\$). 


\section{References}

[1] KJ Chua, SK Chou, WM Yang, J Yan. "Achieving better energy-efficient air conditioning-a review of technologies and strategies." Applied Energy" pp. 87-104 (2013).

[2] Khalid Ahmed Al-Joudi, "Principles Engineering of Refrigeration and Air Conditioning, Second Edition, Faculty of Engineering, Basrah University 1991.

[3] X Zhang, G Xu, KT Chan, X Yi. "A novel energy-saving method for air-cooled chiller plant by parallel connection." Applied thermal engineering "pp.26.16: 2012-2019 (2006).

[4] Chowdhury, Ashfaque Ahmed, M. G. Rasul, and Mohammad Masud Kamal Khan. "Modelling and analysis of air-cooled reciprocating chiller and demand energy savings using passive cooling." Applied Thermal Engineering, Vol.29.8-9,PP. 1825-1830, (2009).

[5] J Jeon, S Lee, D Hong, Y Kim. "Performance evaluation and modeling of a hybrid cooling system combining a screw water chiller with a ground source heat pump in a building." Energy" pp.35.5: 2006-2012, (2010).

[6] X Hao, C Zhu, Y Lin, H Wang, G Zhang, Y Chen. "Optimizing the pad thickness of evaporative air-cooled chiller for maximum energy saving." Energy and Buildings" pp.61: 146-152, (2013).

[7] Kabeel, A. E., Y. A. F. El-Samadony, and M. H. Khiera. "Performance evaluation of energy efficient evaporatively air-cooled chiller." Applied Thermal Engineering,Vol.122,PP. 204213,(2017).

[8] Stanford III, Herbert W. HVAC water chillers and cooling towers fundamentals, application, and operation, 2003.

[9] Sajad Waleed Noori," Study the potential of using Earth to air heat exchanger for cooling and heating of the residential buildings in Iraq " M.Sc. thesis, University of Thi-Qar, Iraq (2018). [10]Y Jiang, Y Yao, S Deng, Z Ma. "Applying grey forecasting to predicting the operating energy performance of air cooled water chillers." International Journal of Refrigeration"pp. 27.4: 385-392, (2004).

[11] Ministry of Electricity [IQ],

https://moelc.gov.iq/. 